\title{
Uji Perbedaan Gaya Belajar Mahasiswa Saat Pembelajaraan Luring
} dan Daring

\author{
Nadya Riri Febiyanti ${ }^{1}$, Dian Cahyawati ${ }^{2 *}$, Anita Desiani ${ }^{3}$, \\ Putra Bahtera Jaya Bangun ${ }^{4}$, Des Alwine Zayanti ${ }^{5}$, \& Endang Sri Kresnawati ${ }^{6}$ \\ 1, 2, 3, 4, 5, 6 Universitas Sriwijaya, Indralaya, Indonesia
}

\section{INFO ARTICLES}

Article History:

Received: 27-11-2021

Revised: 21-12-2021

Approved: 28-12-2021

Publish Online: $31-12-2021$

\section{Key Words:}

Academic Achievement; Learning Style; Online Learning;

\section{c) (†) (?)} ShareAlike 4.0 International License.

\begin{abstract}
Academic achievement is the result of learning obtained by students. Academic achievement can be measured by the achievement value of the academic achievement index. One of the factors that influence academic achievement is learning style. Learning style factors can change as a result of learning changes, such as from offline learning to online learning. The purpose of this study was to examine the significance of the differences in student learning styles during offline learning and online learning. The method used is a quantitative method with Chi-Square test statistical analysis tools. The results showed that students' learning styles were significantly different during offline learning and online learning.
\end{abstract}

\begin{abstract}
Abstrak: Prestasi akademik merupakan hasil pembelajaran yang diperoleh mahasiswa. Prestasi akademik dapat diukur dengan nilai capaian indeks prestasi akademik. Salah satu faktor yang mempengaruhi prestasi akademik adalah gaya belajar. Faktor gaya belajar dapat berubah akibat dari perubahan pembelajaran seperti dari pembelajaran luring menjadi pembelajaran daring. Tujuan dari penelitian ini adalah untuk menguji signifikansi perbedaan antara gaya belajar mahasiswa pada pembelajaran luring dan pembelajaran daring. Metode yang digunakan adalah metode kuantitatif dengan alat analisis statistik uji ChiSquare. Hasil penelitian menunjukkan bahwa gaya belajar mahasiswa berbeda signifikan pada saat pembelajaran luring dan pembelajaran daring.
\end{abstract}

Correspondence Address: FMIPA Unsri Jl. Palembang-Prabumulih km. 32 Indralaya Kab. Ogan Ilir, Sumatera Selatan, Indonesia, Kode Pos 30862; email: dianc_mipa@unsri.ac.id

How to Cite (APA $6^{\text {th }}$ Style): Febiyanti, N.A., dkk. (2021). Uji Perbedaan Gaya Belajar Mahasiswa Saat Pembelajaran Luring dan Daring. JKPM (Jurnal Kajian Pendidikan Matematika), 7(1): $135-142$. http://dx.doi.org/10.30998/jkpm.v7i1.11433

Copyright: 2021 Nadya Riri Febiyanti, Dian Cahyawati, Anita Desiani, Putra Bahtera Jaya Bangun, Des Alwine Zayanti, Endang Sri Kresnawati

Competing Interests Disclosures: The authors declare that they have no significant competing financial, professional or personal interests that might have influenced the performance or presentation of the work described in this manuscript. 


\section{PENDAHULUAN}

Sugiyono (2014) mengemukakan bahwa uji Chi Square $\left(\chi^{2}\right)$ berguna untuk menguji hipotesis komparatif dua sampel jika data yang dianalisis bertipe nominal. Data dengan tipe nominal cukup banyak ditemukan pada kasus pendidikan atau pada kegiatan pembelajaran, misalnya data gaya belajar mahasiswa saat pembelajaran luring dan pembelajaran daring yang diduga dapat mempengaruhi prestasi akademik mahasiswa. Disampikan oleh Malyana (2020), pembelajaran luar jaringan (luring) merupakan suatu pembelajaran yang dilakukan secara tatap muka di kelas sedangkan pembelajaran dalam jaringan (daring) merupakan suatu pembelajaran yang dilakukan secara tatap maya. Kemudian Cahyawati, \& Gunarto (2020) menyebutkan beberapa aplikasi yang digunakan pada pembelajaran daring pada masa awal pandemi meliputi google classroam, zoom, google meet dan whatsapp. Hilmiatussadiah (2020) mengungkapkan adapun faktor-faktor yang mempengaruhi prestasi akademik saat pembelajaran luring dan pembelajaran daring antara lain adalah gaya belajar, lama waktu belajar, jumlah SKS, jumlah kuota internet, kestabilan koneksi internet, perubahan beban tugas yang diberikan kepada mahasiswa, kesulitan mahasiswa memahami materi.

Penelitian ini mengamati faktor gaya belajar mahasiswa pada pembelajaran luring dan pembelajaran daring. Faktor gaya belajar penting diamati karena adanya faktor perubahan pembelajaran pada masa pandemi Covid-19 yang diduga dapat mengubah pola belajar mahasiswa.

Maheni (2019) mengungkapkan bahwa gaya belajar merupakan suatu karakteristik tersendiri yang dimiliki oleh mahasiswa untuk menjadikan pembelajaran lebih efektif dan mudah dimengerti. Terdapat tiga jenis gaya belajar yaitu visual, auditori dan kinestetik. Visual merupakan gaya belajar dengan cara daya tangkap melihat sehingga indera yang dominan adalah indera penglihatan. Auditori merupakan gaya belajar dengan cara daya tangkap mendengar sehingga indera yang dominan digunakan adalah indera pendengaran. Kinestetik merupakan gaya belajar dengan cara daya tangkap melalui gerakan fisik sehingga indera yang dominan adalah indera perasa.

Merujuk dari penelitian Evy (2021) mengenai perubahan gaya belajar mahasiswa, memberikan hasil pembelajaran daring di masa pandemi Covid-19 membawa perubahan gaya belajar mahasiswa. Ada perubahan gaya belajar positif di mana siswa lebih aktif dan kreatif, ada juga perubahan yang negatif di mana terjadinya penurunan motivasi belajar. Sejalan dengan itu, penelitian Widyawati (2016) mengenai gaya belajar mahasiswa dengan menggunakan alat analisis desain faktorial, memberikan hasil penelitian bahwa mahasiswa dengan gaya belajar visual serta auditori memiliki prestasi akademik yang lebih baik dibandingkan mahasiswa dengan gaya belajar kinestetik. Menurut Anggrawan (2019) dalam penelitiannya mengenai gaya belajar mahasiswa menunjukkan mahasiswa dengan gaya belajar auditori dan visual saat pembelajaran daring memiliki rata-rata hasil belajar yang lebih baik dari pada pembelajaran tatap muka sedangkan mahasiswa dengan gaya belajar kinestetik saat pembelajaran daring maupun tatap muka tidak memiliki perbedaan nilai rata-rata hasil belajar. Berdasarkan beberapa hasil penelitian ini, menunjukkan bahwa gaya belajar dapat mempengaruhi hasil belajar namun demikian perlu diungkapkan lebih jauh apakah terdapat perubahan atau perbedaan gaya belajar mahasiswa pada masa pembelajaran luring dan pembelajaran daring.

Penelitian ini akan menguji perbedaan gaya belajar mahasiswa pada saat pembelajaran daring dengan menggunakan statistik uji $\chi^{2}$. Merujuk pada Chislett \& Chapman (2005), instrumen penilaian untuk gaya belajar yang digunakan dalam penelitian ini. 


\section{METODE}

Metode penelitian yang digunakan adalah metode kuantitatif. Populasinya adalah seluruh mahasiswa aktif di Fakultas Matematika dan Ilmu Pengetahuan Alam Universitas Sriwijaya sampai semester ganjil 2020/2021 mahasiswa aktif berjumlah 1882 orang. Teknik sampling yang digunakan adalah proportional simple random sampling dengan ukuran sampel sebanyak 320. Diadopsi dari Chislett \& Chapman (2005), instrumen yang digunakan dalam penelitian ini adalah kuesioner tentang gaya belajar. Uji validitas dan reliabilitas menggunakan rumus koefisien korelasi Product Moment dan menggunakan rumus koefisein Alfa Cronbach. Alat analisis yang digunakan adalah statistik deskriptif dan inferesial dengan uji $\chi^{2}$ (Chi Square). Formulasi statistik uji $\chi^{2}$ adalah

$$
\chi^{2}=\sum \frac{\left(f_{o}-f_{h}\right)^{2}}{f_{h}} \text { (Sugiyono, 2014b) }
$$

Keterangan: $f_{o}=$ banyak kasus pada baris ke-i kolom-j

$f_{h}=$ banyak kasus yang diharapkan pada baris ke-i kolom-j

Kriteria keputusan tolak $H_{0}$ adalah jika $\chi_{\text {nitung }}^{2}>\chi_{\text {tabel }}^{2}$ atau jika nilai signifikan $<\alpha$, dengan tingkat signifikan tertentu.

Uji validitas item pada kuesioner menggunakan teknik korelasi Product Moment dengan $\boldsymbol{\alpha}$ sebesar 0,05 . Formulasi untuk uji validitas adalah

$$
r_{x y}=\frac{n\left(\sum x_{i} y_{i}\right)-\left(\sum x_{1}\right)\left(y_{1}\right)}{\sqrt{\left(n\left(\sum x_{i}^{2}\right)-\left(x_{i}\right)^{2}\right)\left(n\left(\sum y_{i}^{2}\right)-\left(y_{i}\right)^{2}\right)}}(\text { Yusup, 2018) }
$$

Keterangan: $r_{x y}=$ koefisien korelasi Product Moment

$n=$ jumlah responden

$x_{i}=$ skor setiap item pada percobaan pertama

$y_{i}=$ skor setiap item pada percobaan selanjutnya

Koefisien korelasi dikatakan signifikan jika nilai $\boldsymbol{r}_{\text {hitung }}>\boldsymbol{r}_{\text {tabel }}$, semakin tinggi nilai koefisien validitas maka semakin baik instrumen tersebut (Yusup, 2018). Hasil pengujian validitas gaya belajar dengan 11 butir pertanyaan disajikan dalam Tabel 1 .

Tabel 1. Hasil Uji Validitas Instrumen Gaya Belajar

\begin{tabular}{ccccc} 
Butir & $r_{\text {hitung }}$ & Sig. & $r_{\text {tabel }}$ & Kriteria \\
\hline 1 & 0,461 & 0,041 & 0,444 & Valid \\
2 & 0,600 & 0,005 & 0,444 & Valid \\
3 & 0,468 & 0,038 & 0,444 & Valid \\
4 & 0,386 & 0,092 & 0,444 & Tidak Valid \\
5 & 0,575 & 0,008 & 0,444 & Valid \\
6 & 0,447 & 0,048 & 0,444 & Valid \\
7 & 0,503 & 0,024 & 0,444 & Valid \\
8 & 0,709 & 0,000 & 0,444 & Valid \\
9 & 0,650 & 0,002 & 0,444 & Valid \\
10 & 0,583 & 0,007 & 0,444 & Valid \\
11 & 0,579 & 0,007 & 0,444 & Valid \\
\hline
\end{tabular}

Sumber: diolah dari data penelitian, 2021 
Berdasarkan Tabel 1. diperoleh hasil bahwa sepuluh pertanyaan atau butir pada instrument gaya belajar memenuhi uji validitas dan satu pertanyaan yang memiliki status tidak valid yaitu butir 4 . Dengan demikian butir 4 tidak digunakan pada proses pengumpulan data selanjutnya.

Uji reabilitas dilakukan dengan menggunakan rumus Alpha Cronbach, Formulasi untuk pengujian reliabilitas Alpha Cronbach adalah

$$
r_{11}=\left[\frac{k}{k-1}\right]\left[1-\frac{\sum s_{i}^{2}}{s_{i}^{2}}\right](\text { Tarjo, } 2019)
$$

dengan:

$$
s_{i}^{2}=\frac{\sum x^{2}-\frac{\left(\sum x\right)^{2}}{n}}{n}
$$

Keterangan: $r_{11}=$ Reliabilitas instrumen atau koefisien korelasi

$k=$ Banyaknya butir soal

$\sum s_{i}^{2}=$ Jumlah varians butir

$s_{i}^{2}=$ Varians total

$n \quad=$ Jumlah sampel

Kriterianya keputusan reliabilitas jika nilai $r_{\text {hitung }}>r_{\text {tabel }}$ dengan taraf signifikansi $\alpha$ tertentu, maka dapat diputuskan instrumen tersebut reliabel (Tarjo, 2019). Hasil uji reliabilitas instrument ditampilkan pada Tabel $2 .$.

Tabel 2. Hasil Uji Reliabilitas

\begin{tabular}{cccc}
\hline Variabel & $r_{\text {alpha }}$ & $r_{\text {kritis }}$ & Kriteria \\
\hline Gaya Belajar & 0,678 & 0,600 & Reliabel \\
\hline
\end{tabular}

Sumber: diolah dari data penelitian, 2021

Koefisien reliabilitas yang diperoleh adalah 0,678 yang lebih besar dari 0,600 sehingga instrument dapat memenuhi uji reliabilitas. Dengan demikian, instrument dapat digunakan untuk pengukuran variabel gaya belajar.

\section{HASIL}

Deskripsi singkat dari 320 responden berdasarkan asal jurusan (program studi), tingkat semester dan gender mahasiswa disajikan dalam bentuk diagram. Gambar 1. menyajikan karakteristik responden berdasarkan asal prodi.

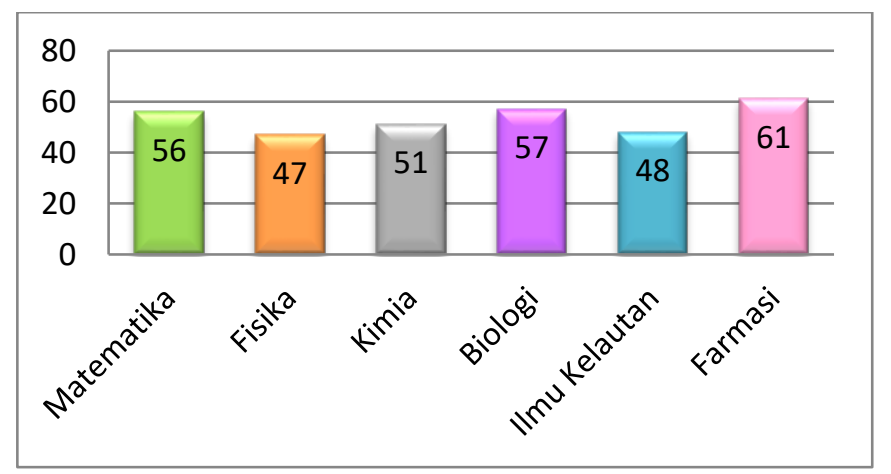

Gambar 1. Karakteristik Responden Berdasarkan Asal Prodi 
Jumlah responden pada setiap prodi ditentukan dengan teknik proportional simple random sampling, jumlah responden untuk setiap prodi relative tidak jauh berbeda karena jumlah mahasiswa di Fakultas MIPA pada setiap angkatan dan setiap prodi serta untuk setiap tahunnya memiliki kuota yang hampir sama. Karakteristik responden berdasarkan semester ditampilkan pada Gambar $2 .$.

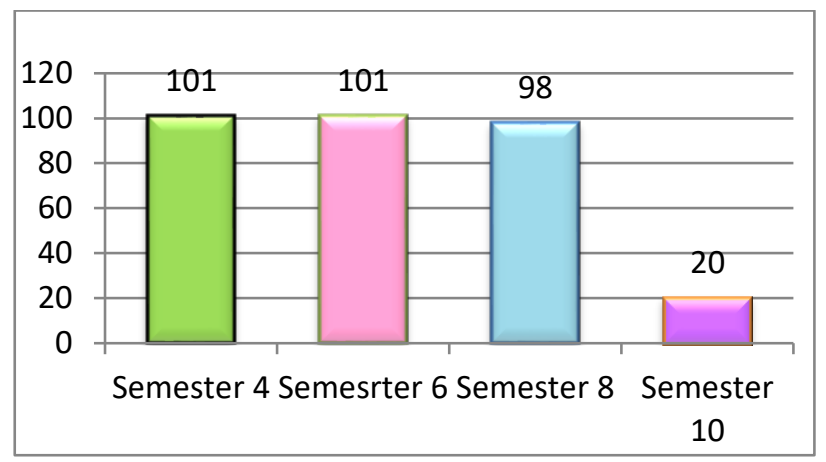

\section{Gambar 2. Karakteristik Responden Berdasarkan Tingkatan Semester}

Gambar 2. menunjukkan jumlah responden adalah mahasiswa semester 10. Jumlah mahasiswa pada semester ini sudah banyak yang menyelesaikan studi dan sudah lulus, sehingga jumlahnya tinggal sedikit. Sedangkan karakteristik responden berdasarkan perbedaan jenis kelamin laki-laki dan perempuan ditampilkan pada Gambar 3.

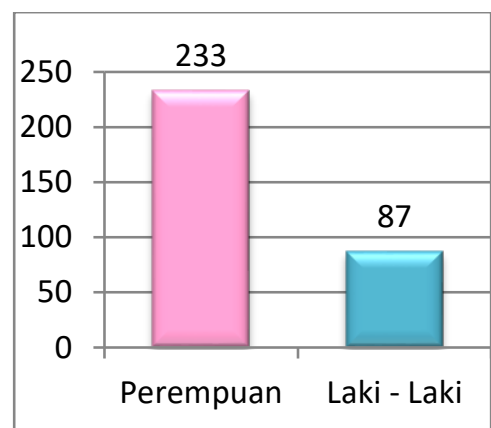

\section{Gambar 3. Karakteristik Responden Berdasarkan Jenis Kelamin}

Gambar 3. menunjukkan bahwa responden perempuan lebih banyak dibandingkan responden lakilaki. Sesuai dengan populasi yang ada di Fakultas MIPA, jumlah mahasiswa perempuan yang memang lebih banyak dibandingkan dengan jumlah mahasiswa laki-laki

Variabel yang diamati adalah gaya belajar mahasiswa pada pembelajaran luring dan pembelajaran daring. Dijelaskan dalam Anggrawan (2019), gaya belajar merupakan suatu karakteristik ataupun ciri khas dari seseorang dalam melaksanakan pembelajaran. Ada empat jenis gaya belajar yaitu visual, auditori, kinestetik maupun campuran. Deskripsi perubahan gaya belajar mahasiswa pada pembelajaran luring dan pembelajaran daring ditampilkan pada Tabel 3..

Tabel 3. menunjukkan adanya perubahan gaya belajar mahasiswa pada saat pembelajaran luring dan pembelajaran daring. Misalnya, ada 101 orang mahasiswa dengan gaya belajar visual pada saat pembelajaran luring, namun pada masa pembelajaran daring berubah menjadi auditori sebanyak 6 orang, dan berubah ke gaya belajar lainnya dengan jumlah yang bervariasi. Namun demikian, ada sejumlah mahasiswa dengan gaya belajar visual tidak berubah yaitu 42 orang tetap pada gaya belajar visual baik pada pembelajaran luring maupun maupun pembelajaran daring. 
Tabel 3. Perubahan Gaya Belajar saat Pembelajaran Luring dan Pembelajaran Daring

\begin{tabular}{cccccccc}
\hline \multirow{2}{*}{$\begin{array}{c}\text { Pembelajaran } \\
\text { Luring }\end{array}$} & Visual & Auditori & Kinestetik & $\begin{array}{c}\text { Visual } \\
\text { dan } \\
\text { Auditori }\end{array}$ & $\begin{array}{c}\text { Visual } \\
\text { dan } \\
\text { Kinestetik }\end{array}$ & $\begin{array}{c}\text { Auditori } \\
\text { dan } \\
\text { Kinestetik }\end{array}$ & Total \\
\hline Visual & 42 & 6 & 33 & 4 & 13 & 3 & 101 \\
Auditori & 15 & 38 & 36 & 9 & 3 & 3 & 106 \\
Kinestetik & 10 & 2 & 41 & 4 & 1 & 4 & 62 \\
$\begin{array}{r}\text { Visual dan } \\
\text { Auditori }\end{array}$ & 2 & 3 & 9 & 8 & 0 & 0 & 22 \\
$\begin{array}{c}\text { Visual dan } \\
\text { Kinestetik }\end{array}$ & 2 & 1 & 7 & 0 & 4 & 1 & 15 \\
$\begin{array}{c}\text { Auditori dan } \\
\text { Kinestetik }\end{array}$ & 2 & 2 & 6 & 1 & 2 & 1 & 14 \\
Total & 73 & 53 & 132 & 26 & 23 & 14 & 320 \\
\hline Sumbelajaran Daring
\end{tabular}

Sumber: diolah dari data penelitian, 2021

Pengujian signifikansi perubahan gaya belajar dari pembelajarn luring ke pembelajaran daring dilanjutkan dengan Uji Chi Kuadrat. Data yang dianalisis untuk diuji signifikansi perbedaan gaya belajar ditampilkan pada Tabel 4 ..

Tabel 4. Kontingensi Gaya Belajar

\begin{tabular}{|c|c|c|c|c|}
\hline \multirow{2}{*}{$\begin{array}{l}\text { Gaya Belajar } \\
\text { Luring }\end{array}$} & \multicolumn{3}{|c|}{ Gaya Belajar Daring } & Total \\
\hline & Kinestetik & Visual & Auditori & \\
\hline Kinestetik & 36 & 31 & 28 & 95 \\
\hline Visual & 7 & 38 & 14 & 59 \\
\hline Auditori & 2 & 5 & 35 & 42 \\
\hline Total & 45 & 74 & 77 & 196 \\
\hline
\end{tabular}

Sumber: diolah dari data penelitian, 2021

Tabel 4. menampilkan data perubahan gaya belajar dari tiga kategori gaya belajar yaitu visual, auditori, dan kinestetik. Gaya belajar dengan kategori kombinasi dari ketiga jenis gaya belajar tidak dianalisis perubahannya sehingga dikeluarkan dari data.

Hipotesis yang diuji adalah

$H_{0}$ : Tidak terdapat perbedaan gaya belajar mahasiswa pada masa pembelajaran luring dan pembelajaran daring.

$H_{1}$ : Terdapat perbedaan gaya belajar mahasiswa pada masa pembelajaran luring dan pembelajaran daring.

Hasil uji statistik dengan formula (1) ditampilkan pada Tabel $5 .$.

Tabel 5. Hasil Uji Chi Kuadrat

\begin{tabular}{cccc}
\hline & Value & df & Asymp. Sig \\
\hline Uji Chi Square $\left(\chi^{2}\right)$ & 64,351 & 4 & 0,000 \\
$\mathrm{~N}$ of Valid Cases & 196 & & \\
\hline \multicolumn{4}{l}{ Sumber: diolah dari data penelitian, 2021}
\end{tabular}

Pada Tabel 5., menunjukkan bahwa hasil dari nilai signifikan yang diperoleh ialah sebesar 0,000, karena nilai signifikan $=0,000<\alpha=0,05$ maka $H_{0}$ ditolak. Artinya dapat disimpulkan bahwa terdapat 
perbedaan yang signifikan antara gaya belajar mahasiswa pada masa pembelajaran luring dan pembelajaran daring.

\section{PEMBAHASAN}

Berdasarkan analisis dan pengujian hipotesis diperoleh hasil bahwa terdapat perbedaan gaya belajar mahasiswa pada masa pembelajaran luring dan pembelajaran daring. Hal ini disebabkan karena proses pembelajaran luring berbeda dengan proses pembelajaran daring. Pembelajaran luring melakukan proses pembelajaran secara tatap muka langsung di kelas sedangkan pada saat pembelajaran daring mahasiswa melakukan proses pembelajaran secara tatap maya di rumah menggunakan fasilitas internet. Pola belajar mahasiswa yang berubah dari luring ke daring menyebabkan gaya belajar mahasiswa juga berubah. Fakta di lapangan pada saat pembelajaran luring mahasiswa dominan dengan gaya belajar kinestetik sedangkan pada saat pembelajaran daring mahasiswa dominan dengan gaya belajar auditori.

Dominannya gaya belajar kinestetik pada pembelajaran luring ditunjukkan dengan banyaknya mahasiswa yang menggunakan sentuhan atau menyentuh objek yang dipelajari dan bahkan sering mempraktikkan hal yang sedang dipelajari secara langsung di kelas. Dominannya gaya belajar auditori pada saat pembelajaran daring ditunjukkan dengan kegiatan belajar yang dilakukan secara tatap maya sehingga mahasiswa lebih cenderung hanya mendengarkan penjelasan-penjelasan materi dari para dosen.

Penelitian ini sejalan dengan penelitian Irsyadi (2021) yang mengungkapkan masing-masing mahasiswa harus menyesuaikan gaya belajar mereka dengan kondisi perkuliahan, hal tersebut penting dilakukan agar mahasiswa dapat memahami materi perkuliahan yang disampaikan dengan baik pada pembelajaran luring maupun daring. Hasil penelitian ini juga sejalan dengan penelitian yang dilakukan oleh Evy (2021) yang memberikan hasil pembelajaran daring membawa perubahan pada gaya belajar mahasiswa. Artinya dengan kata lain gaya belajar mahasiswa saat pembelajaran luring dan pembelajaran daring berbeda. Djamarah \& Zain (2006) mengemukakan bahwa gaya belajar visual, auditori dan kinestetik dimiliki oleh setiap mahasiswa akan tetapi mahasiswa memiliki kecenderungan dari ketiga gaya belajar tersebut, bahkan bisa jadi ada beberapa mahasiswa yang mengkombinasikan gaya belajarnya guna menunjang proses belajar.

Berdasarkan hasil penelitian yang diperoleh, dapat dipertimbangkan untuk menjadi prinsip mahasiswa dalam pembelajaran yaitu tetap berorientasi untuk meningkatkan prestasi akademik dalam berbagai kondisi pembelajaran. Perubahan pelaksanaan pembelajaran dari luring ke daring membawa mahasiswa untuk berubah dalam hal gaya belajarnya, namun mahasiswa cenderung dapat beradaptasi mengikuti pola pembelajaran yang dilaksanakan. Hal ini dapat menjadi kajian lebih lanjut tentang daya adaptasi mahasiswa terhadap teknologi pembeljaran daring. Selain itu, dapat dilanjtukan dengan penelitian menentukan model dugaan pengaruh gaya belajar terhadap prestasi akademik mahasiswa.

\section{SIMPULAN}

Gaya belajar mahasiswa menunjukkan perubahan akibat adanya perubahan pembelajaran luring menjadi pembelajaran daring. Berdasarkan fakta di lapangan, gaya belajar yang dominan dipilih mahasiswa pada pembelajaran luring adalah gaya belajar kinestetik sedangkan gaya belajar yang dominan dipilih mahasiswa pada pembelajaran daring adalah gaya belajar auditori.

Hasil pengujian terhadap signifikansi perbedaan gaya belajar dengan uji chi square mengungkapkan bahwa gaya belajar mahasiswa pada pembelajaran luring berbeda dengan gaya belajar pada saat pembelajaran daring. 


\section{DAFTAR RUJUKAN}

Aldiyah, E. (2021). Perubahan Gaya Belajar Di Masa Pandemi Covid-19. CENDEKIA: Jurnal Ilmu Pengetahuan, 1(1), 8-16. https://doi.org/https://doi.org/10.51878/cendekia.v1i1.24

Anggrawan, A. (2019). Analisis Deskriptif Hasil Belajar Pembelajaran Tatap Muka dan Pembelajaran Online Menurut Gaya Belajar Mahasiswa. MATRIK: Jurnal Manajemen, Teknik Informatika Dan Rekayasa Komputer, 18(2), 339-346. https://doi.org/10.30812/matrik.v18i2.411

Cahyawati, D., \& Gunarto, M. (2020). Persepsi mahasiswa terhadap pembelajaran daring pada masa pandemi Covid-19: Hambatan, tingkat kesetujuan, materi, beban tugas, kehadiran, dan pengelasan dosen. Jurnal Inovasi Teknologi Pendidikan, 7(2), 150-161. https://doi.org/https://doi.org/10.21831/jitp.v7i2.33296

Chislett, V., \& Chapman, A. (2005). VAK Learning Styles Self-Assessment Questionnaire. https://www.businessballs.com/freepdfmaterials/vak_learning_styles_questionnaire.pdf

Djamarah, S., \& Zain, A. (2006). Strategi Belajar Mengajar. Jakarta: Rineka Cipta.

Hilmiatussadiah, K. G. (2020). Hasil belajar mahasiswa pendidikan ekonomi dengan pembelajaran daring pada masa pandemi Covid-19. Jurnal Pendidikan Ekonomi Indonesia, 1(2), 66-69. https://vm36.upi.edu/index.php/JPEI/article/view/26697

Maheni, N. P. K. (2019). Pengaruh Gaya Belajar Dan Lingkungan Teman Sebaya Terhadap Hasil Belajar Mahasiswa Di Jurusan Pendidikan Ekonomi Universitas Pendidikan Ganesha. Jurnal Pendidikan Ekonomi Undiksha, 11(1), 85. https://doi.org/10.23887/jjpe.v11i1.20077

Malyana, A. (2020). Pelaksanaan Pembelajaran Daring Dan Luring Dengan Metode Bimbingan Berkelanjutan Pada Guru Sekolah Dasar Di Teluk Betung Utara Bandar Lampung. Pedagogia: Jurnal Ilmiah Pendidikan Dasar Indonesia, https://doi.org/https://doi.org/10.52217/pedagogia.v2i1.640

Rahmi, I. A. (2021). Gaya Belajar Mahasiswa Selama Kuliah Daring. Kompasiana.

Sugiyono. (2014a). Metode Pendekatan Bisnis (Pendekatan Kuantitatif, Kualitatif dan R\&D). Bandung: Alfabeta.

Sugiyono. (2014b). Metode Penelitian Bisnis (Pendekatan Kuantitatif, Kualitatif dan R\&D) (18th ed.). Bandung: Alfabeta.

Tarjo. (2019). Metode Penelitian Sistem 3X Baca (1st ed.). Bandung: CV Budi Utama.

Widyawati, S. (2016). Pengaruh Gaya Belajar Terhadap Prestasi Belajar Mahasiswa Program Studi Pendidikan Matematika (IAIM NU) Metro. Al-Jabar : Jurnal Pendidikan Matematika, 7(1), 107-114. https://doi.org/10.24042/ajpm.v7i1.135

Yusup, F. (2018). Uji Valditas Dan Reliabilitas Instrumen Penelitian Kuantitatif. Tarbiyah: Jurnal Ilmiah Kependidikan, 7(1), 17-23. https://doi.org/http://dx.doi.org/10.18592/tarbiyah.v7i1.2100 